Article Review

\title{
Pola Penyebaran dan Kelimpahan Bulu Babi Diadema setosum di Indonesia
}

\author{
Andi Halmia* \\ *Jurusan Manajemen Sumber Daya Perairan, Fakultas Perikanan dan IImu Kelautan, Universitas Negeri \\ Gorontalo. Email: andihalmia03@gmail.com
}

\section{Introduction}

Indonesia memiliki perairan laut yang Kaya akan keanekaragaman sumberdaya hayati dan ekosistem trumbu karang yang tinggi, terumbu karang merupakan bagian dari ekosistem laut karena sangat penting menjadi sumber kehidupan bagi keanekaragaman biota laut (Dahuri,2013) dalam (Somma dkk., 2018). Bulu babi yang tergolong fauna invertebrata yang dapat ditemukan pada habitat yang spesifik, seperti zona rataan terumbu karang, daerah pertumbuhan padang lamun, alga , koloni karang hidup dan karang mati (Romimohtarto dan Juwana, 2004; Radjab, 2004; Lawrence, 2007) dalam (Ibrahim dkk 2018). Terdapat kurang lebih 48 jenis Bulu babi di indinesia yang barasal dari 31 Famili, pada umumnya setiap jenis Bulu Babi memiliki sebaran habitat yang spesifik, Bulu Babi tersebar mulai dari daerah intertidal yang dangkal hingga kelaut dalam, Bulu Babi pada umumnya menghuni ekosistem terumbu karang dan padang lamun, yang serta menyukai substrat yang agak keras, terutama substrat di padang lamun yang merupakan campuran dari pasir dan pecahan karang. (Royaldi, dkk 2018). Salah satu spesies bulu babi merupakan kunci komunitas trumbu karang karena bulu babi merupakan salah satu pengendalian populasi dan penurunan makroalga yang terdapat di ekosistem dan tempat terumbu karang akan diimbangkan kembali (Ayyagari dan Kondamudi, 2014) dalam (Juliawan, dkk 2017).

Menurut Hyman (1955) dalam Ratna (2002) bahwa hewan benthonic adalah termasuk bulu babi yang hidup di laut dengan batas kedalaman antara 0-8000 meter. Bulu babi dapat hidup di substrat bebatuan atau terumbu karang dan sebagian kecil hidup di substrat berlumpur dan berpasir. (Afifa, dkk 2018). Menurut Septianti (1994) dalam Huda (2016) keanekaragaman adalah struktur komunitas atau suatu karakteristik tingkat komunitas berdasarkan organisasi biologisnya. Hewan yang sangat penting bagi perairan adalah Bulu babi (Diadema setosum) merupakan hingga hewan ini disebut sebagai kunci bagi daur materi dan aliran energi diperairan (Aziz, 1999 dalam Yulianto, 2012). Menurut Ydasmara (2013) dalam Huda dkk (2017) Keanekaragaman bulu babi dapat di temukan pada zona topografi pantai seperti zona tubir dan lereng terumbu karang,zona pasir, zona tumbuhan lamun dan rumput laut, adanya spesies tertentu ditemukan pada jumlah kelimpahan dan homogenitas substrat indeks keanekaragaman dan kesamarataan jenis bulu babi jadi tinggi rendahnya indeks keanekaragaman akan dapat di pengaruhi oleh beberapa faktor seperti jumlah individu yang ditemukan.

Menurut Akerina dkk (2015) dalam Fitria Hersiana Afifa dkk., (2017), Ada beberapa jenis jenis tertetu pada bulu babi yang mengandung racun dan ada juga jenis bulu babi yang memiliki cangkan yang keras di lapisi oleh pigmen cairan hitam, dibagian tubuh bulu babi 95\% di kelilingi duri duri yang rapuh dan beracun, dduri tersebut dimanfaatkan untuk bergerak, melindungi diri dan mencapit makanannya. Jenis diadema setosum memiliki kelimpahan yang sangat penting bagi terumbu karang karena bisa menyeimbangkan populasi alga dan karang, bulu babi jenis ini dapat di jadikan bioindikator untuk pencemaran logam berat, bulu babi ini sangat berperan penting dalam 
aspek ekonomis salah satunya gonad (telur) dapat di jadikan sebagai makanan yang dapat di konsumsi bagi manusia. (Olii, A. H., \& Kadim, M. K. 2020). Jenis Deadema setusum melakukan mekanisme mempertahankan stressor lingkungan berupa respons terhadap lingkungan dan perilaku atau menutupi dirinya dengan materi di sekitar habitat, berperilaku harian, berpindah, istirahat dan makan, makannya adalah alga hidupnya berkelompok saling melindungi jika terancam musuh. (Rumahlatu, D. 2012). Firmandana,T,C. (2014) Melaporkan bahwa Bulu babi hanya aktif pada malam hari, tujuannya untuk menghindar dari predator. Predator bulu babi ini sangat banyak pada kondisi terumbu karang yang tidak rusak sedangkan, kondisi terumbu karang yang rusak dapat mempengaruhi jumlah predator bagi bulu babi, dan dari kondisi ini juga yang menyebabkan terumbu karang di kenal sebagai ekosistem yang memiliki keanekaragaman jenis jenis organisme yang menempatinya paling besar besar. Kelimpahan bulu babi dalam perairan di pengerahui oleh keberadaan substrat dan keberedaan bulu babi pada suatu ekosistem tidak terlepas dari pengaruh faktor fisika dan kimia. (Noviana, dkk 2019).

Pada umumnya setiap jenis bulu babi tersebar mulai dari daerah intertidall yang dangkal kelaut dalam dan memiliki sebaran habitat yang spesifik ( Jeng, 1998 dalam Mistiasih, 2013) dalam ( Baruadi,H. 2017). Bulu babi mempunyai bermacam macam jenis kepadatan relatif yang lebih rendah di bandingkan jenis $D$. Setosum, tetapi tidak begitu jauh berbedanya di antara jenis- jenis tersebut. Adapun hewan-hewan telah di temukan hidup sendiri-sendiri maupun hidup berkelompok pada beberapa tempat ditemukan. Bulu babi umumnya hewan nokturnal atau aktif dimalam hari tersebut, dan bulu babi pada disiang hari agak bersembunyi di celah-celah karang, dan keluar pada malam hari untuk mencari makanan (Zakaria, I. J. 2013). Bulu babi (echinoidea) berhabitat di kawasan terumbu karang (Nane et al., 2020). Bulu babi juga ditemukan di kawasan di daerah padang lamun (Nane, 2019b). Persebaran bulu babi (echinoidea) tergantung terhadap faktor ketersediaan makanan maupun perkembangan faktor substrat tersebut. Karena besarnya Indonesia seperti wilayah sublitarol perairan Iboih Kec. Sukakarya Kota Sabang. Sebagian kawasan terumbu karang, terumbu karang tersebut adalah habitat dan persebaran bulu babi (echinoidea). Atas kehadiran bulu babi (echinoidea) adalah yang cukup merata maupun dapat jadikan indikator kerusakan terumbu karang pada bulu babi. (Annisa, R. 2019).

Heliocidaris crassispina adalah salah satu jenis bulu babi spesies indo-pasifik mempunyai didaerah sebaran yang sempit terutama itu di Cina maupun Jepang Selatan, Spesies ini sebenarnya telah banyak orang diteliti di negara korea Selatan, Cina dan Jepang sebagai Anthocidaris crassispina. Bahwa studi terbaru genetik berdasarkan Anthocidaris adalah suatu sinonim muda dari heliocidaris tersebut. (Hart, et al. 2011; Agatsuma, 2013; Kroh, 2014; Jung, et al. 2015) dalam (Hasi, dkk 2016). Menurut odum (1992) dalam Noviana dkk (2019) Nilai indeks kesergaman tergolong dalam komunitas labil karena diduga penyebaran individu yang tidak merata. Jenis keanekaragaman dapat pengaruhi oleh pembagian atau penyebaran tiap jenis individunya. Lndak laut (Echinometra mathaei) Jenis bulu babi lain yang memiliki duri berbisa Jenis ini telurnya juga belum diekploitasi untuk bahan makanan dan lebih berperan sebagai bahan hiasan akuarium. (Syam, A. R., \& Andamari, R. 2017). Mengkonsumsi gonad (telur) sebagai bahan pangan memiliki kandungan zat gizi yang tinggi seperti glikogen, kalsium, fosfor, protein, lipid, kemudian vitamin yang terkandung yakni Vitamin A,B,B2, B12, asam nikotinik, asam pantotenik, kirotin dan asam folik (Kato dan schroetef,1985 dalam Toha, 2006) dalam (Padang,A, dkk 2019). Hewan Bulu babi merupakan penentu kelimpahan dan sebaran tumbuhan laut di perairan laut yang dangkal. Maupun Agregasi yang padat dari bulu babi bertanggung jawab atas hancurnya komunitas ganggang laut dan mampu merusaknya komunitas lamun di beberapa daerah pantai di daerah tropis maupun daerah subtropis (Valentine dan Heck, 1991) dalam (Moningkey 2010). Bulu babi yang hidup dipadang lamun bisa bertahan hidup di soliter atau hidup mengelompok, tergantung kepada jenis-jenis tersebut maupun habitatnya misalnya yang cenderung hidup mengelompok: contoh jenis T. ventricosus, Lytechinus variegatus, Temnopleurus toreumaticus dan 
Strongylocentrotus spp, Diadema setosum, D. antillarum, Tripneustes gratilla. Sedangkan cenderung hidup menyendiri: contoh jenis Pseudoboletia maculata, dan Echinothrix diadema, Mespilia globulus, Toxopneustes pileolus. (Aziz, 1994: 36) dalam (Lubis, dkk 2017).

Bulu babi atau vertebrata laut merupakan filum echinodermata yang tersebar di daerah intertidal yang dangkal hingga di dasar laut,keystone spesies atau spesie kunci sebagai bulu babi merupakan komunitas terumbu karang sangat menurun populasinya akibat bulu babi penyebab matinya terumbu karang. Krna populasinya makroalgae bisa meningkat apabila bulu babi tidak menganggu habitatnya terumbu karang. Karena makroalgea akan mendominasi menutup wilayah karang. (Nystrom et al, 2000) dalam ( Miala, dkk 2015). Fachrul (2008) dalam Irianto, A., Jahidin, J., \& Sudrajat, H. W. (2016). Menyatakan bahwa di perairan memiliki nilai yang dominan Tekanan ekologi terjadi dikarenakan terjadi labil pada struktur komunikasi. Dan suatu biota tertentu di perairan memiliki nilai dominansi mendekati dari nol, berarti struktur dalam komunikasi biota merupakan dalam keadaan stabil, dan sebaliknya apabila nilai dominansi dari 1. Dari hasi penelitian Laning, T.H., (2014 ) melaporkan bahawa di Indonesia bagian pantai Merta sena, Sanur Bali. Bahwa populasi bulu babi di pantai merta segara dan sanur, termasuk atau katagori keadaan sedang $\left(\mathrm{H}^{\prime}=\right.$ 1-3), penyebaran merata $(E=0,76)$ dan dominansi rendah $(0,25)$.

Kepadatan dan jumlah jenis bulu babi dipengaruhi oleh keberadaan aktivitas masyarakat dan tipe substrat pasir halus sebagai habitatnya. Bulu babi kerap di temukan dikawasan padang lamun, diwilayah pantai merta segara dan sanur. Sanur terdiri 9 spesies dari 5 family, yaitu Diadema savignyi, Diadema setosum, Diadema palmeri, Echinothrix calamaris, Echinometra mathei, Echinocardium sp., Mespilia globulus, Tripneustues gratilla dan Toxopneustes sp. Bulu babi hampir semua zone lautan tersebar. Ada beberapa hewan dalam filum echinodermata saat ini sangat beragam. Telah diketahui sekitar sebesar 800 spesies bulu babi di dunia. Adapun beberapa di perairan indomalaya (perairan Indonesia, Filipina, malaysia sebagian wilayah Australia Utara) telah diketahui berjumlah sekitar 316 spesies tersebut. Khusus perairan Indonesia diketahui sekitar 84 jenis yang telah bergabung dalam 48 marga dan 21 suku. Bulu babi tersebut berasal dari berbagai spesies, genus, family maupun ordo. Toha, A. H. A. (2019).

Bulu babi saat ini di Indonesia belum dimanfaatkan secara komersial karena pemanfaatannya hanya sebagai pakan ternak tambahan dan sebagai lauk pauk terutama masyarakat pesisir. Hewan ini memiliki nilai ekonomis yang tinggi terutama gonadnya sebagai komoditas ekspor (Zakaria 2013 dalam Suseno, S. H., \& Jacoeb, A. M. 2014; Nane, 2019a; Nane 2020). Bulu babi untuk dapat hidup pada kondisi lingkungan yang sangat memungkinkan, berkembang biak, juga beradaptasi hal ini didasari oleh karakteristik dari Bulu babi yang umumnya hidup pada substrat berupa karang maupun pecahan karang (rubble). (Yudasmara, G. A. 2013). Dari daerah pasang surut hingga kedalaman 5000 meter dan umumnya dijumpai pada zona litoral, yaitu dari batas pasang daerah tertinggi sampai paparan benua. bulu babi termasuk dalam Filum Echinodermata, Kelas Echinoidea yang menghuni perairan laut pada segala jenis dasar berkisar (Hyman, 1955) dalam ( Alamrie, M., Lalita, J. A., \& Kaligis, E. 2013)

Tjendanawangi (2010) dalam Tupan, J., \& br Silaban, B. (2017) Tipe substrat bulu babi yang didominasi oleh campuran pasir berlumpur dan pecahan karang serta ditumbuhi oleh lamun yang pendek dengan kerapatan lamun yang tidak padat, biasanya memperlihatkan bobot tubuh yang lebih kecil. Tipe substrat yang didominasi oleh campuran dan menjelaskan bobot tubuh bulu babi yang ditangkap di alam berkaitan dengan tipe substrat di habitatnya juga substrat pasir berlumpur dan pecahan karang serta ditumbuhi oleh lamun yang agak tinggi dengan kerapatan lamun bervariasi tetapi ditumbuhi oleh berbagai jenis makroalga, umumnya memperlihatkan bobot tubuh yang besar. Tingginya tutupan vegetasi lamun di perairan banyak biota yang berasosiasi dengan ekosistem padang lamun termasuk bulu babi untuk mencari makan, tempat hidup, memijah 
dan tempat berlindung juga untuk menghindari predator juga. Echinodermata merupakan salah satu biota yang berasosiasi kuat dengan ekosistem padang lamun dan berperan dalam siklus rantai makanan di ekosistem tersebut. (Supono, 2010) dalam (Purnomoa, dkk 2019). Keberadaan bulu babi di Kawasan padang lamun berkaitan erat dengan aktivitas makannya sebagai grazer utama pada daerah padang lamun, biologi bulu babi telah dilakukan di berbagai tempat di dunia,meliputi studi mikrohabitatnya (Agustia 2016 dalam Yudi, K., Risandi, D. P., \& Rika, K.)

Pada hal ini terjadi saat bulu babi memakan lamun akan ada sisa lamun atau lamun tersebut terputus sehingga dimanfaatkan oleh organisme lain atau diuraikan oleh dentritus. Lamun yang diuraikan oleh dentritus menjadi bahan organik akan digunakan oleh hewan-hewan invertebrata lainnya dan juga digunakan oleh plankton-plankton, yang membuat padang lamun akan semakin banyak dihuni oleh berbagai jenis ikan karena ketersediaan plankton (Unsworth, Taylor, Powell, Bell, \& Smith, 2007). (Lawrence, 2007a) dalam (Yulianto, A. R. 2012). Pengambilan bulu babi di alam secara berlebihan atau terus menurus tanpa mempertimbangkan asepek pola penyebaran dan kelimpahan juga kelestariannya akan berdampak negatif dengan menurunnya populasi tersebut. Hal ini berkaitan dengan tingkat kepadatan populasi untuk organisme yang mendiami daerah tropis pada umumnya mempunyai tingkat kepadatan yang rendah. Penurunan bulu babi di alam akan semakin cepat jika tingkat eksploitasinya berlebih (Nane \& Paramata, 2020). Apalagi bila penambahan individu baru (rekruitment) dari populasi tersebut tidak sebanding dengan hasil tangkapan. Diperkirakan tingkat eksploitasi sumberdaya bulu babi di alam telah melebihi batas yang diperbolehkan (overexploitation) (Hammer et al., 2006) dalam (Uneputty, dkk 2017)

\section{Conclusion}

Terdapat kurang lebih 48 jenis Bulu babi di indinesia yang barasal dari 31 Famili, pada umumnya setiap jenis Bulu Babi memiliki sebaran habitat yang spesifik, Bulu Babi tersebar mulai dari daerah intertidal yang dangkal hingga kelaut dalam, Bulu Babi pada umumnya menghuni ekosistem terumbu karang dan padang lamun, yang serta menyukai substrat yang agak keras, terutama substrat di padang lamun yang merupakan campuran dari pasir dan pecahan karang. Bulu babi untuk dapat hidup pada kondisi lingkungan yang sangat memungkinkan, berkembang biak, juga beradaptasi hal ini didasari oleh karakteristik dari Bulu babi yang umumnya hidup pada substrat berupa karang maupun pecahan karang (rubble). Bulu babi yang hidup dipadang lamun bisa bertahan hidup di soliter atau hidup mengelompok, tergantung kepada jenis-jenis tersebut maupun habitatnya misalnya yang cenderung hidup mengelompok: contoh jenis $T$. ventricosus, Lytechinus variegatus, Temnopleurus toreumaticus dan Strongylocentrotus spp, Diadema setosum, D. antillarum, Tripneustes gratilla. Sedangkan yang cenderung hidup menyendiri: contoh jenis Pseudoboletia maculata, dan Echinothric diadema, Mespilia globulus, Toxopneustes pileolus. Tipe substrat yang didominasi oleh campuran dan menjelaskan bobot tubuh bulu babi yang ditangkap di alam berkaitan dengan tipe substrat di habitatnya juga substrat pasir berlumpur dan pecahan karang serta ditumbuhi oleh lamun yang agak tinggi dengan kerapatan lamun bervariasi tetapi ditumbuhi oleh berbagai jenis makroalga, umumnya memperlihatkan bobot tubuh yang besar. Tingginya tutupan vegetasi lamun di perairan banyak biota yang berasosiasi dengan ekosistem padang lamun termasuk bulu babi untuk mencari makan, tempat hidup, memijah dan tempat berlindung juga untuk menghindari predator juga. Echinodermata merupakan salah satu biota yang berasosiasi kuat dengan ekosistem padang lamun dan berperan dalam siklus rantai makanan di ekosistem tersebut. Pengambilan bulu babi di alam secara berlebihan atau terus menurus tanpa mempertimbangkan asepek pola penyebaran dan kelimpahan juga kelestariannya akan berdampak negatif dengan menurunnya populasi tersebut. Hal ini berkaitan dengan tingkat kepadatan populasi untuk organisme yang mendiami daerah tropis pada umumnya mempunyai tingkat kepadatan yang rendah. 


\section{Reference}

Afifa, F. H., Supriharyono, S., \& Purnomo, P. W. (2018). Penyebaran Bulu Babi (Sea Urchins) Di Perairan Pulau Menjangan Kecil, Kepulauan Karimunjawa, Jepara. Management of Aquatic Resources Journal, 6(3), 230-238.

Alamrie, M., Lalita, J. A., \& Kaligis, E. (2013). Pengaruh Berbagai Jenis Alga Mikro Pada Pertumbuhan Larva Pluteus Bulu Babi Echinometra Mathaei Tipe A Hasil Fertilisasi Buatan. Jurnal $\begin{array}{lllll}\text { Pesisir Dan Laut } & \text { Tropis, } & \text { 1(1), }\end{array}$ Https://Ejournal.Unsrat.Ac.Id/Index.Php/Jplt/Article/View/1293

Annisa, R. (2019). Kelimpahan Dan Pola Sebaran Bulu Babi Yang Berasosiasi Dengan Artificial Patch Reef (Apr) Dan Natural Reef Di Pulau Panjang Jepara (Doctoral Dissertation, Faculty Of Fisheries And Marine Sciences). Http://Eprints.Undip.Ac.Id/77165/

Baruadi, H. (2017). Kepadatan Dan Pola Sebaran Bulu Babi (Echinoidea) Di Desa Lamu Kecamatan Batudaa Pantai Kabupaten Gorontalo. Skripsi, 1(633411037). Http://Repository.Ung.Ac.Id/Skripsi/Show/633411037/Kepadatan-Dan-Pola-Sebaran-BuluBabi-Echinoidea-Di-Desa-Lamu-Kecamatan-Batudaa-Pantai-Kabupaten-Gorontalo.Html

Firmandana, T. C. (2014). Kelimpahan Bulu Babi (Sea Urchin) Pada Ekosistem Karang Dan Lamun Di Perairan Pantai Sundak, Yogyakarta. Management Of Aquatic Resources Journal, 3(4), 41-50. Https://Ejournal3.Undip.Ac.Id/Index.Php/Maquares/Article/View/7030

Hasi, M. S., Lumingas, L. J., \& Lohoo, A. V. Analisis Allometri Dan Indeks Fisiologis Bulu Babi Heliocidaris Crassispina (A. Agassiz, 1864)(Camarodonta, Echinometridae) Di Rataan Terumbu Tongkeina Dan Malalayang Dua, Manado, Sulawesi Utara1. https://Pdfs.Semanticscholar.Org/99b5/6b790fa4f2ea5c1f0e74ba026f00716e6d4a.Pdf

Huda, M. A. I. (2016). Keanekaragaman Jenis Echinoidea Di Zona Intertidal Pantai Jeding Taman Nasional Baluran. Https://Repository.Unej.Ac.Id/Handle/123456789/76681

Huda, M. A. I., Sudarmadji, S., \& Fajariyah, S. (2017). Keanekaragaman Jenis Echinoidea Di Zona Intertidal Pantai Jeding Taman Nasional Baluran. Berkala Sainstek, 5(2), 61-65. Https://Jurnal.Unej.Ac.Id/Index.Php/Bst/Article/View/5531

Irianto, A., Jahidin, J., \& Sudrajat, H. W. (2016). Kelimpahan Bulu Babi (Echinoidea) Di Intertidal Perairan Pulau Liwutongkidi Kecamatan Siompu Kabupaten Buton Selatan. Jurnal $\begin{array}{llll}\text { Ampibi (Almuni } & \text { Pendidikan } & \text { Biologi), }\end{array}$ Http://Ojs.Uho.Ac.Id/Index.Php/Ampibi/Article/View/5034/3757

Ibrahim, I., Devira, C. N., \& Purnawan, S. (2018). Struktur Komunitas Echinoidea (Bulu Babi) Di Perairan Pesisir Pantai Teluk Nibung Kecamatan Pulau Banyak Kabupaten. Aceh Singkil. Prosiding Biotik, 4(1). Https://Jurnal.ArRaniry.Ac.Id/Index.Php/Pbiotik/Article/View/2145/1598

Juliawan, J., Dewiyanti, I., \& Nurfadillah, N. (2017). Kelimpahan Dan Pola Sebaran Bulu Babi (Echinodea) Di Perairan Pulau Klah Kota Sabang. Jurnal IImiah Mahasiswa Kelautan Perikanan Unsyiah, 2(4). Http://Www.Jim.Unsyiah.Ac.Id/Fkp/Article/View/7777

Kakilo, M. R. (2020). Pemanfaatan Bulu Babi (Diadema Setosum) Sebagai Kebutuhan Farmatologi Dan Sumber Pangan. Https://Osf.lo/Am735

Laning, T. H., Yusup, D. S., \& Wiryatno, J. (2014). Sebaran Bulu Babi (Echinoidea) Di Kawasan Padang Lamun Pantai Merta Segara, Sanur-Bali. Jurnal Biologi Udayana, 18(2).

Lubis, S. A., Purnama, A. A., \& Yolanda, R. (2017). Spesies Bulu Babi (Echinoidea) Di Perairan Pulau Panjang Kabupaten Bangka Tengah Provinsi Bangka Belitung. Jurnal IImiah Mahasiswa Fkip Prodi Biologi, 3(1) Http://EJournal.Upp.Ac.Id/Index.Php/Fkipbiologi/Article/View/1134

Miala, I., Pratomo, A., \& Irawan, H. (2015). Hubungan Antara Bulu Babi, Makroalgae Dan Karang Di Perairan Daerah Pulau Pucung. Repository Umrah. www.Jurnal.Umrah.Ac.ld 
Moningkey, R. D. (2010). Pertumbuhan Populasi Bulu Babi (Echinometra Mathaei) Di Perairan Pesisir Kima Bajo Kabupaten Minahasa Utara. Jurnal Perikanan Dan Kelautan Tropis, 6(2), 7378. https://Ejournal.Unsrat.Ac.Id/Index.Php/Jpkt/Article/View/164/135

Nane, L. (2019a). Efisiensi Mesin Teknologi Sapurata Dalam Mengoptimalisasi Produksi Inovasi Pangan Kukure Di Pulau Barrang Lompo, Makassar. https://doi.org/10.31230/osf.io/q8spg

Nane, L. (2019b). Impact of overfishing on density and test-diameter size of the sea urchin Tripneustes gratilla at Wakatobi Archipelago, south-eastern Sulawesi, Indonesia. BioRxiv, 727271. https://www.biorxiv.org/content/10.1101/727271v1

Nane, L., \& Paramata, A. R. (2020). Impact of Overfishing on Density and Test-Diameter Size of the Sea Urchin Tripneustes gratilla at Wakatobi Archipelago, South-Eastern Sulawesi, Indonesia. ILMU KELAUTAN: Indonesian Journal of Marine Sciences, 25(2), 53-56. https://doi.org/10.14710/ik.ijms.25.2.53-56

Nane, L. (2020). Pemanfaatan Telur Landak Laut Diadema setosum di Pulau Taliabu, Maluku Utara, Indonesia. https://doi.org/10.31219/osf.io/kmtuv

Nane, L. (2019c). Sea Urchin Sustainability Studies Based on Dimension Biology, Ecology and Technology at Around of Tolandono Island and Sawa Island at Wakatobi Conservation Area. https://doi.org/10.31230/osf.io/4whz6

Nane, L. (2019d). Studi Keberlanjutan Perikanan Landak Laut Berdasarkan Dimensi Biologi, Ekologi Dan Teknologi Di Sekitar Pulau Tolandono Dan Pulausawa Kawasan Konservasi Wakatobi [Skripsi, Universitas Hasanuddin]. https://Marxiv.Org/9zdvr/

Nane, L., Baruadi, A. S. R., \& Mardin, H. (2020). The density of the blue-black urchin Echinotrix diadema (Linnaeus, 1758) in TominiBay, Indonesia. Tomini Journal of Aquatic Science, 1(1), 16-21. https://doi.org/10.37905/tjas.v1i1.5939

Noviana, N. P. E., Julyantoro, P. G. S., \& Pebriani, D. A. A. (2019). Distribusi Dan Kelimpahan Bulu Babi (Echinoidea) Di Perairan Pulau Pasir Putih, Desa Sumberkima, Buleleng, Bali. $\begin{array}{llll}\text { Current } \quad \text { In } & \text { Aquatic } & \text { Science, } & \text { 2(1), }\end{array}$ https://Ojs.Unud.Ac.Id/Index.Php/Ctas/Article/View/42514

Olii, A. H., \& Kadim, M. K. (2020). Kepadatan Dan Pola Sebaran Bulu Babi Di Desa Lamu| Density And Distribution Patterns Of Sea Urchin In Lamu Village. Jurnal Nike, 5(2). Http://Ejurnal.Ung.Ac.Id/Index.Php/Nike/Article/View/5279.

Padang, A., Nurlina, N., Tuasikal, T., \& Subiyanto, R. (2019). Kandungan Gizi Bulu Babi (Echinoidea). Agrikan: Jurnal Agribisnis Perikanan, 12(2), 220227.Https://Www.Stipwunaraha.Ac.Id/Ejournal/Index.Php/Agrikan/Article/View/297

Purnomoa, I. G. P. A., Dharma, I. S., \& Putraa, I. N. G. Struktur Komunitas Dan Sebaran Bulu Babi (Echinoidea) Di Kawasan Padang Lamun Pantai Serangan, Bali.

Rumahlatu, D. (2012). Respons Perilaku Bulu Babi Deadema Setosum Terhadap Logam Berat Kadmium. Bumi Lestari Journal of Environment, 12(1), 45-54.

Royadi, A., Dewi, P., \& Eko, N. Jenis Dan Kelimpahan Bulu Babi Di Perairan Desa Sekunyit Kabupaten Kaur Provinsi Bengkulu (Doctoral Dissertation, Universitas Bengkulu). Http://Repository.Unib.Ac.Id/18374/

Samuel, P. (2016). Jenis Dan Kelimpahan Bulu Babi (Diadematidae): Coral Bioeroder Pada Kondisi Tekanan Lingkungan Yang Berbeda (Doctoral Dissertation, Universitas Brawijaya). http://Repository.Ub.Ac.Id/157844/

Syam, A. R., \& Andamari, R. (2017). Populasi Dan Tingkat Pemanfaatan Bulu Babi (Echinoidea) Di Padang Lamun Pulau Osi, Seram Barat, Maluku Tengah. Jurnal Penelitian Perikanan Indonesia, 8(4\}31-37. http://Ejournal- Balitbang.Kkp.Go.Id/Index.Php/Jppi/Article/View/4824

Somma, A., Zahida, F., \& Yuda, P. (2018). Kelimpahan Dan Pola Penyebaran Bulu Babi (Echinoidea) Di Terumbu Karang Pantai Pasir Putih, Situbondo, Indonesia. Biota: Jurnal IImiah IImu-IImu Hayati,3(2), 111-115. Https://Ojs.Uajy.Ac.Id/Index.Php/Biota/Article/Viewfile/1887/1255 
Suseno, S. H., \& Jacoeb, A. M. (2014). Profil Asam Lemak Dan Asam Amino Gonad Bulu Babi. Jurnal Pengolahan Hasil Perikanan Indonesia, Https://Jurnal.Ipb.Ac.Id/Index.Php/Jphpi/Article/View/8138

Uneputty, P. A., Pattikawa, J. A., \& Rijoly, F. (2017). Status Populasi Bulu Babi Tripneustes Gratilla Di Perairan Desa Liang, Pulau Ambon. Omni-Akuatika, 12(3). Http://Ojs.Omniakuatika.Net/Index.Php/Joa/Article/View/131/69

Toha, A. H. A. (2019). Keragaman Genetik Bulu Babi (Echinoidea). Biota: Jurnal IImiah IImu-IImu Hayati, 12(2), 131-135. Https://Ojs.Uajy.Ac.Id/Index.Php/Biota/Article/Viewfile/2669/1554

Tupan, J., \& Br Silaban, B. (2017). Karakteristik Fisik-Kimia Bulu Babi Diadema Setosum Dari Beberapa Perairan Pulau Ambon. Triton, 13(2), 71-78. Https://Www.Neliti.Com/Publications/286862/Karakteristik-Fisik-Kimia-Bulu-Babi-DiademaSetosum-Dari-Beberapa-Perairan-Pulau

Yudi, K., Risandi, D. P., \& Rika, K. Kondisi Bulu Babi (Echinoidea) Dan Habitatnya Di Pulau Buyu Lingga. Kondisi Bulu Babi (Echinoidea) Dan Habitatnya Di Pulau Buyu Lingga. Http://Repository.Umrah.Ac.Id/689/

Yudasmara, G. A. (2013). Keanekaragaman Dan Dominansi Komunitas Bulu Babi (Echinoidea) Di Perairan Pulau Menjangan Kawasan Taman Nasional Bali Barat. Jst (Jurnal Sains Dan Teknologi), 2(2).

Yulianto, A. R. (2012). Pemanfaatan Bulu Babi Secara Berkelanjutan Pada Kawasan Padang Lamun. Program Studi IImu Lingkungan Program Pascasarjana, Universitas Indonesia. Thesis (Tidak Dipublikasikan).

Zakaria, I. J. (2013). Komunitas Bulu Babi (Echonoidea) Di Pulau Cingkuak, Pulau Sikuai Dan Pulau Setan Sumatera Barat. Prosiding Semirata http://Jurnal.Fmipa.Unila.Ac.Id/Semirata/Article/View/681 